\title{
PERILAKU HARIAN GAJAH SUMATERA (Elephas maximus sumatranus) DI ELEPHANT RESPON UNIT TAMAN NASIONAL WAY KAMBAS LAMPUNG
}

\author{
(The Daily behavior of Sumatran Elephant (Elephas maximus sumatranus) in Elephant \\ Response Unit Way Kambas National Park Lampung)
}

\author{
Alponsus Alpiadi, Erianto, Hari Prayogo \\ Fakultas Kehutanan Universitas Tanjungpura, Jalan Imam Bonjol Pontianak 78124 \\ E-mail : alpiadi.alponsus@yahoo.com
}

\begin{abstract}
Indonesia has a high wealth of flora and fauna, wealth is necessary guarded and preserved, one of the wealth fauna owned Indonesia is Sumatran Elephant (Elephas maximus sumatranus) . This study aims to record the daily behavior of Sumatran Elephant (Elephas maximus sumatranus) in Elephant Response Unit Way Kambas National Park Lampung. The method used is focal animal sampling. The method was chosen because it allows the observer to record any behavior that occurs suddenly and quickly by recording animal behavior at certain time intervals. The results obtained from six individual tame elephants that became objects named Karnangin, Aditya, Dona, Wulan, Elena, and Cory consisted of 13 daily behaviors which were dominated by eating. Daily behavior found differences on adult male elephants named Karnangin and Aditya commonly used for patrol activities and when not patrolling. Sumatran elephants need food availability like green plants in their habitat, because less perfect digestion of these animals requires very large amounts of food, 200 - $300 \mathrm{~kg}$ of biomass per day for each adult elephant tail or 5-10\% of his body weight.
\end{abstract}

Keywords: Daily Behavior, Focal Animal Sampling, Sumatran Elephants

\section{PENDAHULUAN}

Indonesia memiliki kekayaan flora dan fauna yang tinggi, kekayaan tersebut perlu dijaga dan dilestarikan. Salah satu kekayaan fauna yang dimiliki Indonesia yaitu spesies Gajah Sumatera (Elephas maximus sumatranus). Gajah Sumatera (Elephas maximus sumatranus Temminck 1847) merupakan salah satu kekayaan fauna Indonesia yang termasuk satwa langka berdasarkan UU No. 05 tahun 1990 tentang Konservasi Sumberdaya Alam Hayati dan Ekosistemnya. Gajah sumatera tergolong satwa terancam punah (endangered) dalam Red List Data Book IUCN (International Union for Conservation of Nature and Natural Resources) (IUCN, 2018).

Perburuan satwa liar hingga konflik antara gajah dan manusia masih sering terjadi. Mitigasi konflik dan upaya konservasi yang berkelanjutan terus dilakukan oleh Elephant Respon Unit di Taman Nasional Way Kambas. Gajah pada dasarnya sangat selektif dalam memilih habitatnya, karena satwa ini memiliki kepekaan yang tinggi dalam memperhitungkan berbagai kondisi habitat, misalnya ketersediaan tempat 
mencari makan, penutupan tajuk sebagai tempat berlindung dan tersedianya sumber air. Perilaku harian dan pemilihan unit habitat diduga sangat dipengaruhi oleh kondisi habitat dan posisi unit habitat essensial dalam suatu ekosistem. Habitat gajah meliputi seluruh hutan di Pulau Sumatera dari Lampung sampai Provinsi Aceh, mulai dari hutan basah berlembah dan hutan payau di dekat pantai sampai hutan pegunungan pada ketinggian $2000 \mathrm{~m}$.

Sebagai satwa yang dilindungi dan patut untuk dilestarikan maka gajah sumatera perlu mendapatkan perhatian khusus. Belum adanya data mengenai perilaku harian gajah jinak di Elephant Respon Unit, Tegal Yoso Taman Nasional Way Kambas, penelitian mengenai perilaku harian gajah sumatera ini perlu untuk dilakukan sebagai bahan evaluasi serta bahan pertimbangan rencana dari kegiatan konservasi terhadap perlakuan yang perlu diberikan pada gajah sumatera. Hal ini demi kelangsungan hidup satwa secara lestari dan dapat mempermudah dalam melihat perkembangan perilaku harian gajah sumatera.

Tujuan penelitian ini adalah untuk mendata perilaku harian Gajah Sumatera (Elephas maximus sumatranus) di Elephant Respon Unit Taman Nasional Way Kambas Lampung. Manfaat penelitian ini diharapkan mampu memberikan informasi mengenai perilaku harian Gajah Sumatera (Elephas maximus sumatranus) di Elephant Respon Unit Taman Nasional Way Kambas
Lampung. Hasil penelitian ini diharapkan dapat membantu merancang program rehabilitasi yang lebih tepat bagi Gajah Sumatera.

\section{METODE PENELITIAN}

Penelitian dilakukan di Elephant Respon Unit Tegal Yoso, Taman Nasional Way Kambas, Lampung. Penelitian dilakukan selama satu bulan lima belas hari dimulai dari 15 Oktober 2018 sampai 30 November 2018. Alat yang digunakan selama kegiatan penelitian antara lain headlamp, lembar pengamatan (tally sheet), alat tulis, jam tangan, kamera digital, dan kalkulator. Objek penelitian ini adalah enam ekor gajah jinak bernama Karnangin (jantan dewasa), Aditya (jantan dewasa), Dona (betina dewasa), Wulan (betina dewasa), Ellena (betina anak), Cory (jantan anak). Penelitian dilakukan dengan menggunakan metode focal animal sampling. Metode tersebut dipilih karena memungkinkan pengamat mencatat setiap perilaku yang terjadi secara tiba-tiba dan cepat. Teknik pencatatan perilaku satwa pada interval waktu tertentu (Martin dan Bateson,1993). Pengamatan dilakukan pada pukul 08.00-21.00 WIB selama 13 jam perhari dengan cara mencatat frekuensi perilaku berdasarkan durasi waktu yang ditentukan yaitu setiap interval 2 menit.

Perilaku harian yang diamati meliputi :

- Makan : Proses makan dan diberi makan.

- Minum : Minum secara langsung dan diberi minum. 
- Berpindah : Berpindah dari satu tempat ketempat lain.

- Menggaram : Memakan bagian tanah atau menjilati bagian tubuh yang mengandung garam mineral.

- Berkubang : Berendam, menyembur air dan mandi

- Istirahat : Perilaku diam beristirahat atau tidur.

- Grooming : Perilaku merawat diri dengan cara menggaruk, menggosok, membersihkan

bagian tubuh ke pohon atau secara langsung atau menggunakan bagian tubuh lainnya.

- BAB : Proses Defekasi atau Mengeluarkan feces pada organ pencernaan.

- BAK : Proses Urinasi

Mengeluarkan urine pada organ pencernaan.

- Menyembur Tanah : Menyemburkan tanah kepunggung atau bagian tubuh lain untuk melindungi tubuh.

- Menyusui : Gajah betina dewasa menyusui gajah anak.

- Menyusu : Gajah anak menyusu pada gajah betina dewasa.

- Bermain : Beradu gading dan saling berdorongan kontak fisik sesama gajah

Data yang diperoleh dari hasil pengamatan langsung dicatat kedalam lembar pengamatan, kemudian dimasukkan kedalam diagram proporsi. Diagram tersebut akan digunakan untuk melihat presentase waktu tiap perilaku. Persamaan yang digunakan yaitu :
Presentase suatu perilaku (\%)

$=\frac{\mathrm{X}}{\mathrm{Y}} \mathrm{x} 100 \%$

Keterangan :

$\mathrm{X}$ : Frekuensi Perilaku

Y : Total Frekuensi

Data yang telah diperoleh dianalisis secara deskriptif kuantitatif. Deskriptif kuantitatif yaitu suatu bentuk penelitian berdasarkan data yang dikumpulkan selama penelitian secara sistematis mengenai fakta-fakta dan sifat-sifat objek yang diteliti, kemudian diinterprestasikan berdasarkan teoriteori dan literatur-literatur yang berhubungan dengan penelitian. Hasil analisis ini kemudian akan ditampilkan dalam bentuk grafik dan tabel.

\section{HASIL DAN PEMBAHASAN}

Perilaku harian gajah dipengaruhi oleh jenis kelamin, umur, peran dalam kelompok serta keberadaan lingkungannya. Gajah merupakan hewan sosial yang hidup berkelompok, kelompok berperan penting dalam menjaga kelangsungan hidup gajah. Enam individu gajah jinak bernama Karnangin, Aditya, Dona, Wulan, Elena, dan Cory ditemukan adanya perbedaan perilaku harian pada gajah jantan dewasa bernama Karnangin dan Aditya yang biasa digunakan untuk kegiatan patroli dan pada saat tidak patroli. Gajah betina sangat jarang digunakan dalam menangani konflik atau patroli, sementara gajah anak tidak dipergunakan dalam patroli hal ini dipengaruhi oleh rentannya keselamatan gajah dan mahout (pawang gajah) serta faktor kondisi habitat yang hanya dapat dijangkau oleh gajah tertentu. 
Tabel 1. Persentase Perbandingan Perilaku Harian Gajah (Percentage Comparison Daily Behavior of Elephant)

\begin{tabular}{|c|c|c|c|c|c|c|c|c|}
\hline \multirow{3}{*}{ Perilaku Harian } & \multicolumn{8}{|c|}{ Persentase $(\%)$} \\
\hline & \multicolumn{2}{|c|}{ Patroli } & \multirow[b]{2}{*}{ Karnangin } & \multirow[b]{2}{*}{ Aditya } & \multirow[b]{2}{*}{ Dona } & \multirow[b]{2}{*}{ Wulan } & \multirow[b]{2}{*}{ Elena } & \multirow[b]{2}{*}{ Cory } \\
\hline & Karnangin & Aditya & & & & & & \\
\hline Makan & 41,74 & 42,24 & 63,93 & 60,74 & 55,85 & 54,24 & 51,49 & 47,50 \\
\hline Minum & 2,07 & 2,30 & 1,69 & 1,36 & 1,66 & 1,92 & 1,62 & 4,19 \\
\hline Berpindah & 36,24 & 36,70 & 15,88 & 18,70 & 29,97 & 28,43 & 29,73 & 27,59 \\
\hline Menggaram & 0,27 & 0,22 & 0,70 & 0,51 & 0,33 & 0,31 & 1,52 & 1,08 \\
\hline Istirahat & 14,93 & 13,66 & 11,21 & 9,76 & 4,05 & 9,42 & 10,07 & 10,56 \\
\hline Grooming & 0,27 & 0,44 & 0,45 & 0,60 & 0,64 & 0,75 & 1,00 & 0,88 \\
\hline $\mathrm{BAB}$ & 1,74 & 1,70 & 1,37 & 1,63 & 1,36 & 1,39 & 1,01 & 0,81 \\
\hline BAK & 0,60 & 1,04 & 0,61 & 0,66 & 0,46 & 0,56 & 0,11 & 0,13 \\
\hline Menyembur Tanah & 1,04 & 0,55 & 1,53 & 3,26 & 1,23 & 0,95 & 0,96 & 2,31 \\
\hline Menyusu & - & & - & - & - & - & - & 2,62 \\
\hline Menyusui & - & & - & - & 2,62 & - & - & - \\
\hline Berkubang & 0,87 & 0,93 & 1,60 & 1,75 & 1,81 & 2,02 & 1,42 & 1,3 \\
\hline Bermain & 0,22 & 0,22 & 1,02 & 1,03 & - & - & 1,06 & 1,04 \\
\hline Total & 100 & 100 & 100 & 100 & 100 & 100 & 100 & 100 \\
\hline
\end{tabular}

\section{Karnangin}

Gajah yang diamati yaitu Karnangin berumur 31 tahun merupakan gajah jantan dewasa yang berasal dari gajah liar Mesuji Lampung Utara diambil pada tahun 1995 pada umur 8 tahun. Gajah Karnangin merupakan gajah jantan dewasa yang sering digunakan dalam kegiatan patroli, perilaku harian yang terjadi pada gajah jantan umunya lebih besar dibandingkan kelompok betina terutama pada perilaku makan $63,93 \%$ dan istirahat $11,21 \%$ terkecuali perilaku berpindah $15,88 \%$. Hal ini dipengaruhi oleh sifat gajah jantan dewasa yang lebih tenang dalam melakukan perilaku hariannya dilihat dari ukuran tubuh yang lebih besar dan adanya gading yang dimiliki. Perilaku harian gajah pada saat patroli ada perbedaan yang disebabkan oleh perlakuan perilaku secara khusus oleh mahout dalam hal menjaga kesehatan gajah dan mendukung kegiatan patroli serta mitigasi konflik antara gajah dan manusia. Belalai gajah pada umumnya akan digerakkan memanjang, melingkar atau menggulung ketika gajah akan menggapai makanannya (Abdullah et al, 2006). Perilaku harian Karnangin ditunjukkan pada gambar 1 dan 2 . 


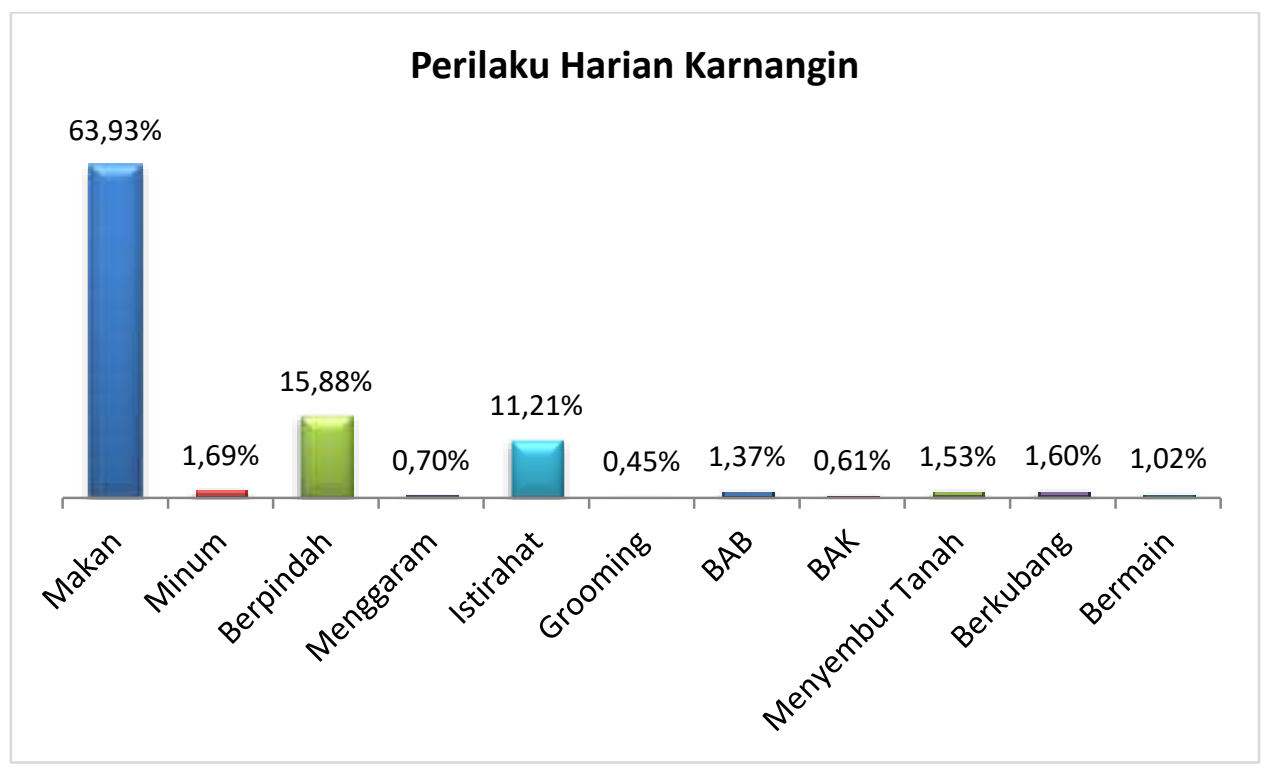

Gambar 1. Persentase Perilaku Harian Karnangin (Percentage Daily Behavior of Karnangin)

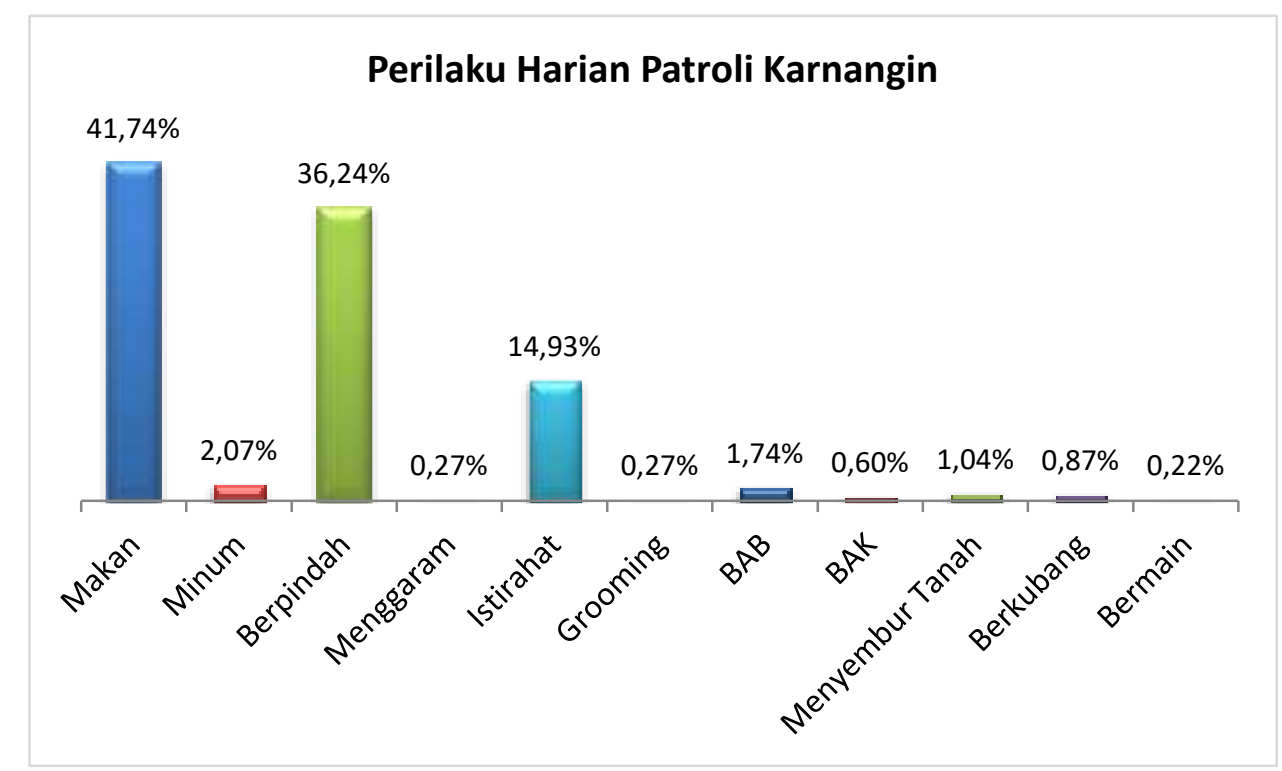

Gambar 2. Persentase perilaku harian paroli Karnangin (Percentage Daily Behavior Patrol of Karnangin)

\section{Aditya}

Aditya berumur 28 tahun merupakan gajah jantan dewasa berasal dari gajah liar di TNWK yang ditangkap pada tahun 1997 pada umur 7 tahun. Gajah Aditya merupakan gajah jantan remaja yang termasuk dalam bagian gajah patroli. Perilaku harian gajah pada perilaku istirahat 9,76\% sedikit lebih kecil dibandingkan gajah Karnangin hal ini dipengaruhi besar oleh perilaku harian berpindah 18,70 \% . Perilaku harian Aditya ditunjukkan pada gambar 3 dan 4 . 


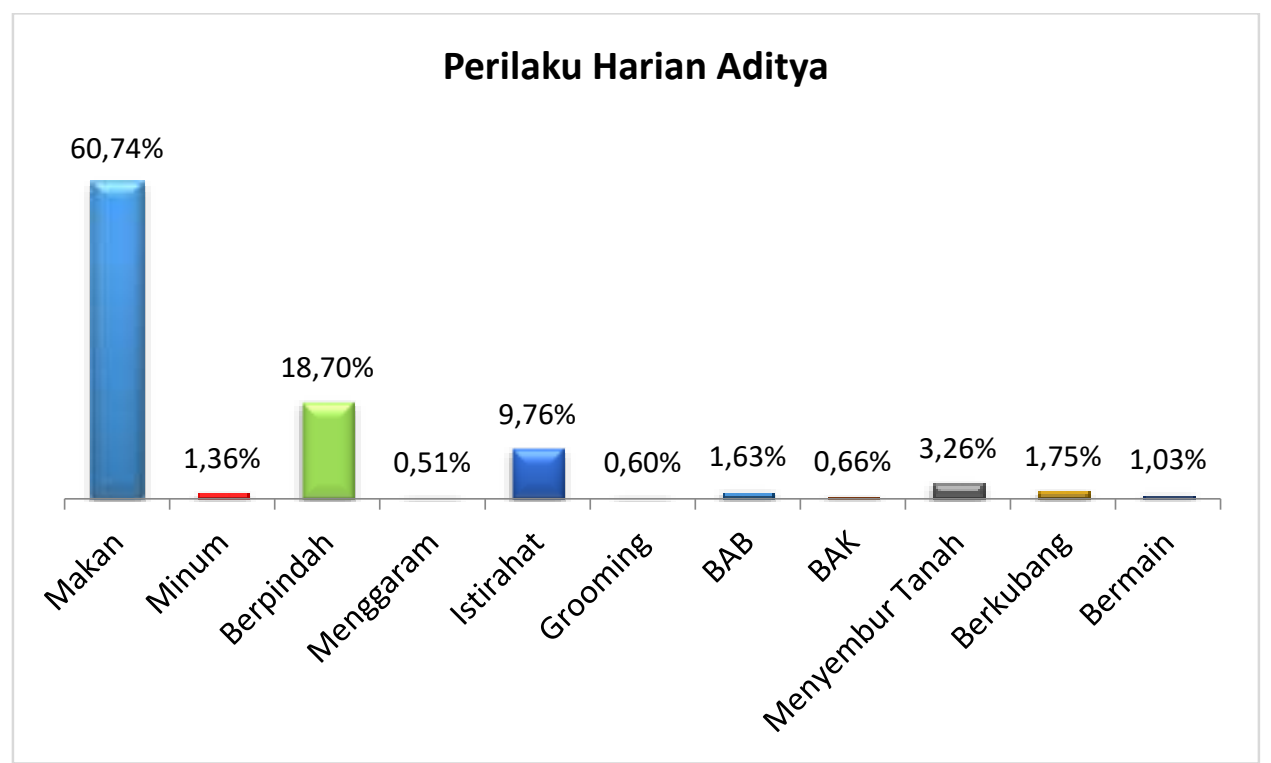

Gambar 3. Persentase Perilaku Harian Aditya (Percentage Daily Behavior of Aditya)

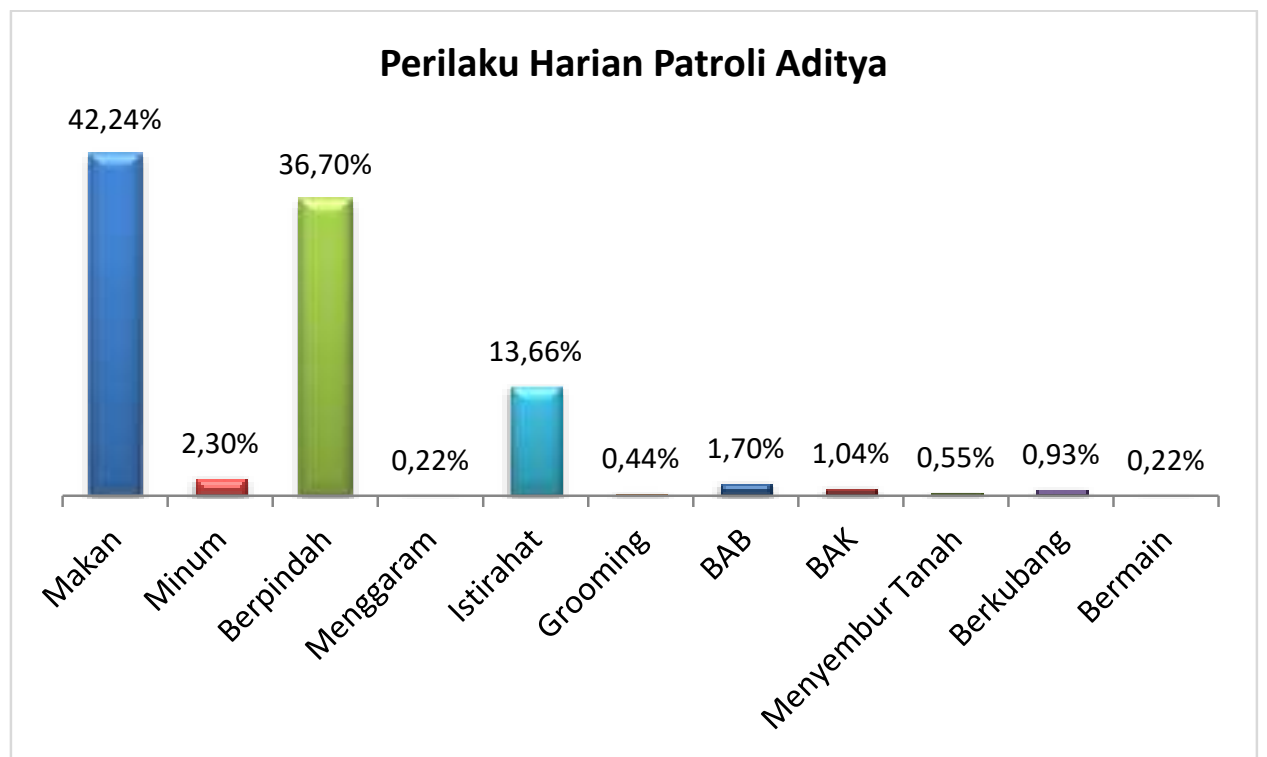

Gambar 4. Persentase Perilaku Harian Patroli Aditya (Percentage Daily Behavior Patrol of Aditya)

\section{Dona}

Dona berumur 37 tahun merupakan gajah betina dewasa berasal dari gajah liar di TNWK yang ditangkap pada tahun 1997 pada umur 16 tahun. Berdasarkan postur tubuh, umur yang paling tua dalam kelompok dan menjadi pemimpin saat terjadi perilaku berpindah, Dona merupakan ketua kelompok dari empat invidu gajah jinak yaitu gajah Wulan, Elena dan Cory dan juga merupakan induk dari Cory (gajah anak). Hal ini yang mempengaruhi besarnya perilaku makan Dona yaitu 
dengan jumlah persentase 55,85 \% dikarenakan Dona yang masih menyusui 2,62\%. Besarnya perilaku berpindah 29,97\% pada gajah Dona dikarenakan tingginya tingkat tanggung jawab dan kewaspadaan dalam mempertahankan kelompoknya yang berakibat kecilnya persentasi istirahat gajah Dona 4,05\%. Perilaku harian Dona ditunjukkan pada gambar 5.

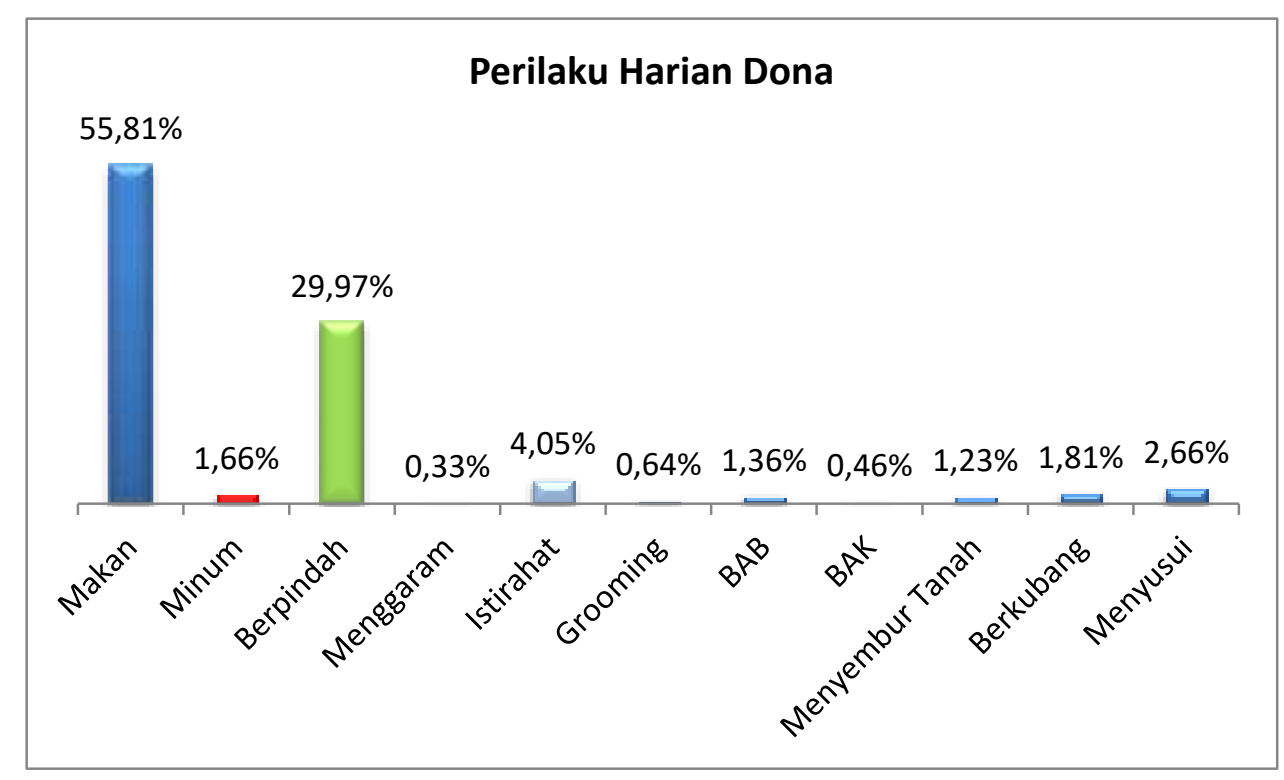

Gambar 5. Persentase Perilaku Harian Dona (Percentage Daily Behavior of Dona)

\section{Wulan}

Wulan berumur 15 tahun merupakan gajah betina dewasa yang lahir di Pusat Latihan Gajah (PLG) TNWK yang dijinakkan sejak anak. Wulan pada saat pengamatan sedang dalam kondisi hamil sekitar 19 bulan hal ini mempengaruhi persentase perilaku berpindah Wulan yaitu $28,43 \%$ dan perilaku istirahat dengan persentase $9,42 \%$. Perilaku harian Wulan ditunjukkan pada gambar 6.

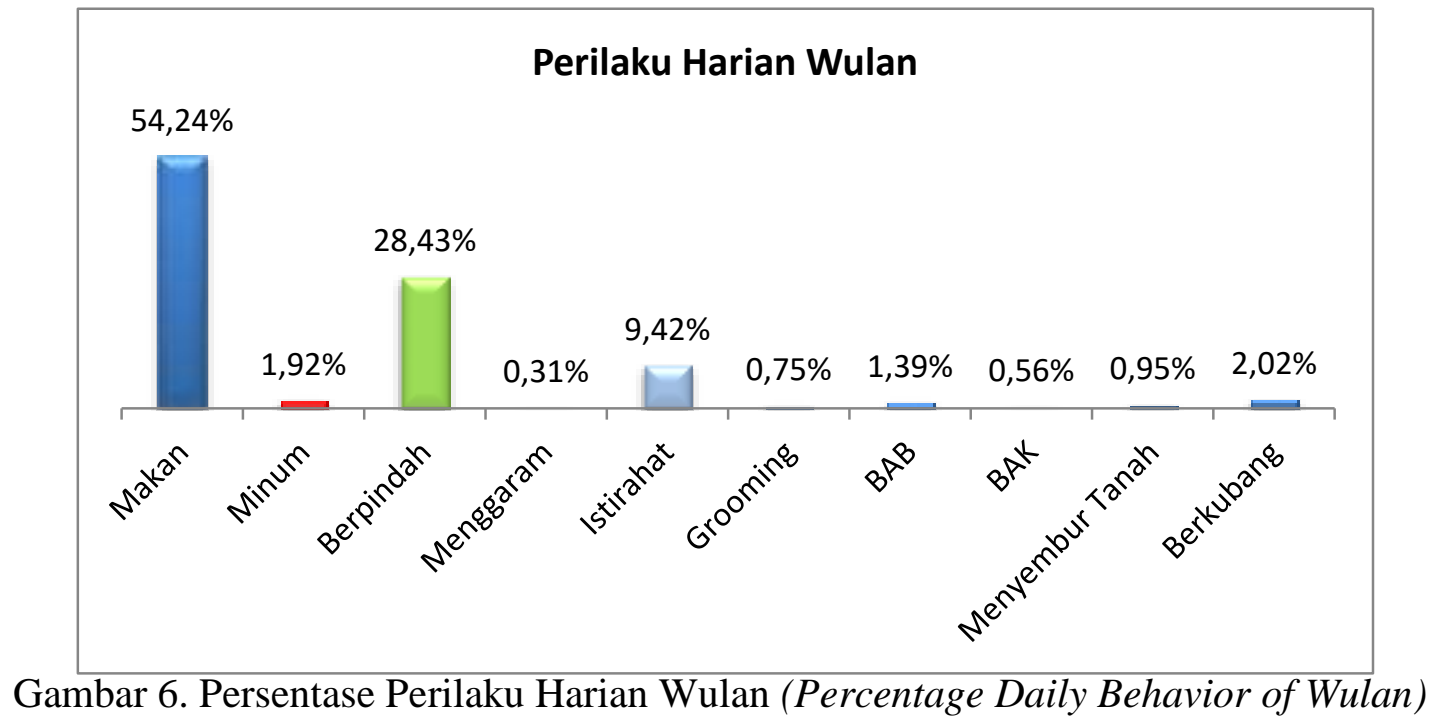




\section{Elena}

Elena berumur 4 tahun merupakan gajah betina anak yang ditangkap dari penyelamatan gajah liar di TNWK. Elena pada saat ini berada dalam kelompok gajah Dona, perilaku gajah Elena pada umunya hampir sama dengan gajah Cory namun terjadi perbedaan pada perilaku makan dengan persentase 51,49 \% yang dikarenakan pada gajah Elena tidak ditemukan adanya perilaku menyusu. Perilaku harian Elena ditunjukkan pada gambar 7 .

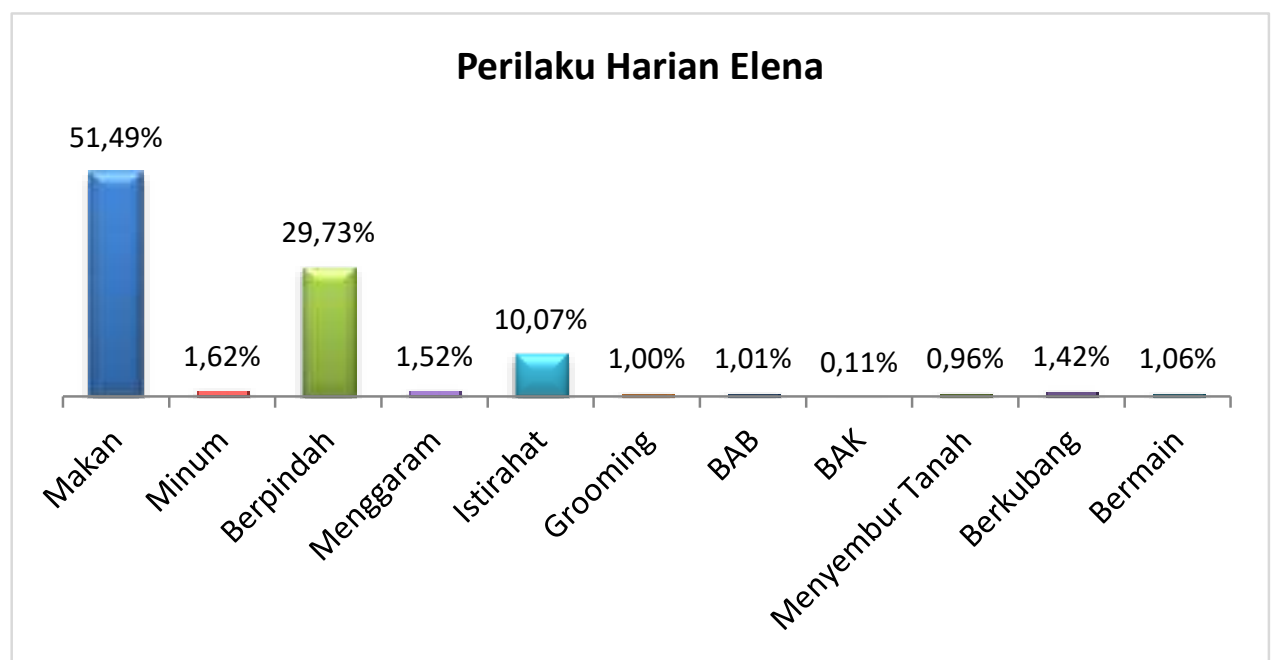

Gambar 7. Persentase Perilaku Harian Elena (Percentage Daily Behavior of Elena)

\section{Cory}

Cory berumur 1,5 tahun merupakan gajah jantan anak yang lahir di Camp ERU Tegal Yoso TNWK. Perilaku harian pada gajah anak Cory memperoleh persentasi perilaku makan sebesar 47,50 \% ini merupakan persentase perilaku makan terkecil dalam kelompok gajah Dona yang dipengaruhi oleh faktor perilaku menyusu $2,62 \%$ dan perilaku minum $4,19 \%$ serta besarnya perilaku istirathat $10,56 \%$ dibandingkan gajah lainnya yang berada dalam kelompok. Perilaku harian Cory ditunjukkan pada gambar 8 .

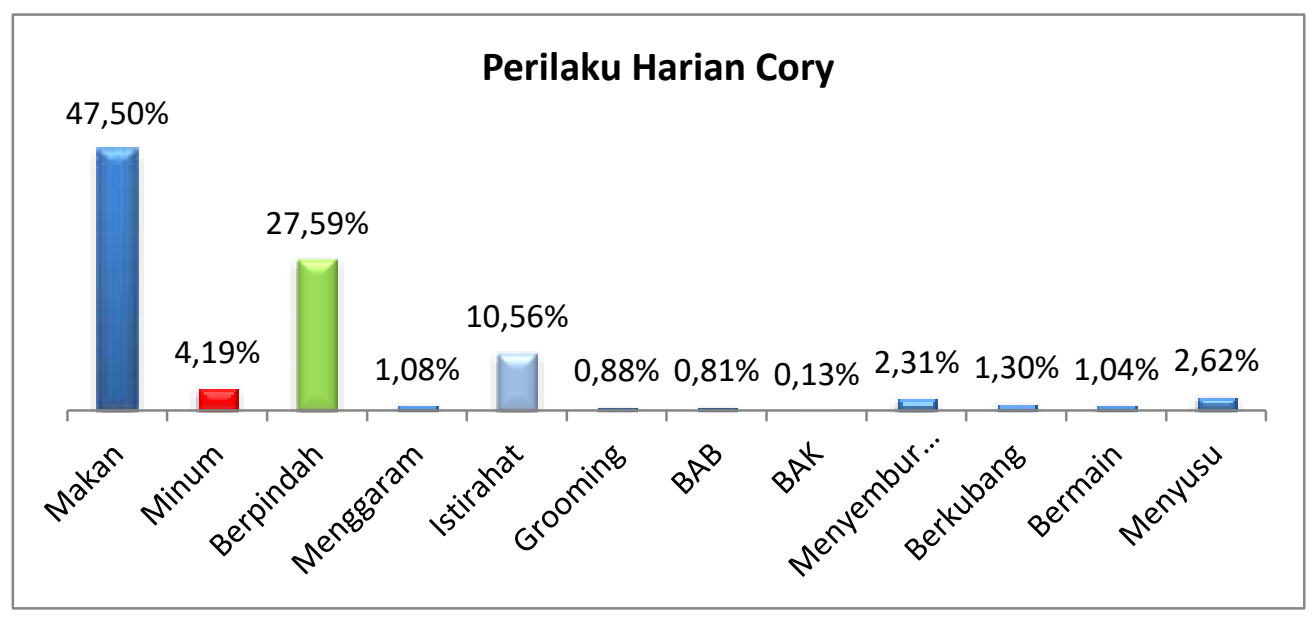

Gambar 8. Persentase Perilaku Harian Cory (Daily Behavior of Cory) 
Perilaku tertinggi yang diperoleh pada keenam individu gajah jinak di Elephant Respon Unit (ERU) Tegal Yoso TNWK pada saat pengamatan

Tabel 2. Persentase Perilaku Makan (Percentage of Eating)

\begin{tabular}{clr}
\hline No & Nama & $\%$ \\
\hline 1 & Karnangin & 63,93 \\
2 & Karnangin (P) & 41,74 \\
3 & Aditya & 60,74 \\
4 & Aditya (P) & 42,24 \\
5 & Dona & 55,81 \\
6 & Wulan & 54,24 \\
7 & Elena & 51,49 \\
8 & Cory & 47,50 \\
\hline
\end{tabular}

Keterangan $: \mathrm{P}=$ Perilaku pada saat patrol $(P=$ Patrol Behavior $)$

Perilaku makan tertinggi diperoleh pada gajah Karnangin dengan persentase $63,93 \%$ dan terendah diperoleh dari gajah Cory dengan persentase 47,50 \%. Perbedaan ini dipengaruhi oleh postur tubuh Karnangin yang lebih besar serta umur yang membutuhkan asupan makanan lebih banyak sementara Cory masih menyusu. Perilaku makan gajah hampir dilakukan setiap saat dan merupakan perilaku tertinggi pada setiap gajah hal ini dipengaruhi oleh besarnya kebutuhan gajah dalam memenuhi jumlah makanan yang akan dikonsumsinya. Perilaku makan berkurang terjadi pada siang hari dan tengah malam hari yang disebabkan gajah membutuhkan waktu untuk beristirahat. Menurut Lakgul dan McNelly (1977) dan Abdillah (2010) Gajah Sumatera membutuhkan ketersediaan makanan berupa tumbuhantumbuhan hijau yang cukup dihabitatnya, karena pecernaan yang kurang sempurna satwa ini membutuhkan makanan yang sangat banyak yaitu $200-300 \mathrm{~kg}$ biomassa perhari untuk setiap ekor gajah yaitu perilaku makan dengan persentasi makan dari masing-masing individu adalah sebagai berikut.

dewasa atau 5-10\% dari berat badannya selain itu gajah juga membutuhkan garam mineral untuk memenuhi kebutuhannya, kekurangan garam mineral pada tumbuhan yang dimakan oleh gajah menyebabkan gajah melakukan perilaku menggaram secara alami dengan mencari sumber lain seperti memakan tanah dihutan atau lokasi tertentu ( Ayeni, 1972).

\section{Kesimpulan}

1. Perilaku harian gajah besar dipengaruhi oleh jenis kelamin, umur, peran dalam kelompok serta keberadaan lingkungannya. Gajah merupakan hewan sosial yang hidup berkelompok, kelompok berperan penting dalam menjaga kelangsungan hidup gajah. Jumlah anggota kelompok sangat bervariasi tergantung pada kondisi sumber daya alam dan luas habitat, setiap kelompok dipimpin oleh seekor betina dewasa sedangkan yang jantan berada dalam kelompk untuk periode tertentu saja. 
2. Penelitian dilakukan pada 6 (enam) individu gajah jinak bernama Karnangin, Aditya, Dona, Wulan, Elena dan Cory. Persentase Perilaku harian didominasi oleh perilaku makan dengan persentase tertinggi pada gajah jantan dewasa yaitu Karnangin 63,93 \% dan terendah oleh gajah jantan anak Cory. $47,50 \%$.

3. Hasil penelitian menunjukkan bahwa perilaku tertinggi yang diperoleh dari keenam individu gajah jinak di Elephant Respon Unit (ERU) Tegal Yoso TNWK pada saat pengamatan yaitu perilaku makan, hal ini diindikasikan bahwa gajah berada dalam kondisi sehat, dikarenakan adanya perilaku berpindah menunjukkan bahwa gajah tidak mengalami stress ataupun sakit serta diimbangi dengan perilaku istirahat yang cukup dialami oleh gajah.

\section{Saran}

1. Perlu dilakukan penelitian lebih lanjut untuk gajah sumatera yang berada dalam kawasan tertentu terkait kesejahteraan gajah pada habitatnya guna melihat perkembangan kemampuan gajah dalam beradaptasi dan perlakuan konservasi yang tepat bagi gajah sumatera.

2. Perlu dilakukan penelitian pada musim dan waktu yang berbeda dengan waktu penelitian ini.

\section{UCAPAN TERIMA KASIH}

Penulis mengucapkan banyak terima kasih kepada Bapak Ir. H. Erianto, MP,
Bapak Dr. Hari Prayogo, S.Si, M.Si, Kepala Balai Taman Nasional Way Kambas, Koordinator serta rekan-rekan Mahout di Elephant Respon Unit TNWK, Rekan-rekan serta Keluarga besar angkatan 2014 Fakultas Kehutanan Universitas Tanjungpura,Kedua Orang tua dan seluruh pihak yang telah membantu dalam penelitian ini.

\section{DAFTAR PUSTAKA}

Abdillah H. 2010. Gajah Sumatera: Mamalia Besar Sumatera yang Diambang Kepunahan. http://www.indotoplist.com/info/. Diakses 3 November 2018.

Abdullah, Dahlian, dan Mukhlisin. 2006. Preferensi Makan Gajah Sumatera (Elephas maximus sumatranus) di Kawasan Hutan Cagar Alam Jantho. Jurnal Pendidikan Biologi FKIP Unsyiah. 7 (2): 65-67.

Ayeni S O. 1972. Chemical analysis of some soil samples from aatural licks. East Africa wildlife Journals. 2:16-23

IUCN (International Union for Conservation of Nature and Natural Resources). 2018. IUCN Red List Endangered Species.http://www.iucnredlist. org /search. Diakses 17 Juli 2018.

Lekagul B dan J A McNeely. 1977. Mammals of Thailand. The Association for The Conservation of Wildlife. Bangkok.

Martin P, Bateson P. 1993. Measuring Behaviour, An introducing guide. 2nd Ed. Cambridge University Press. Cambridge. 